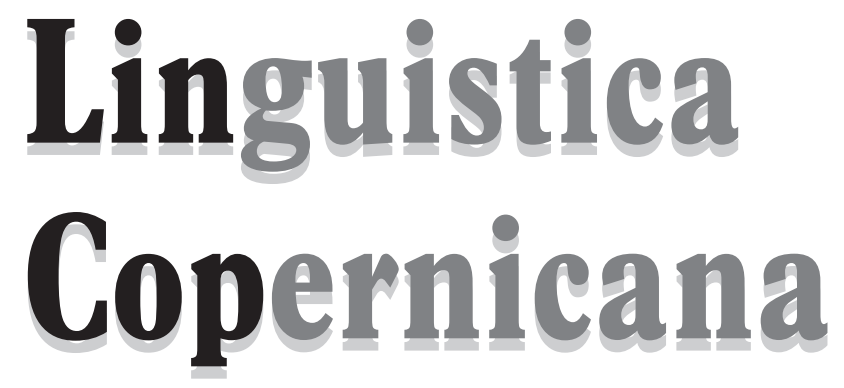

$1(7) / 2012$

WYDAWNICTWO NAUKOWE
UNIWERSytetu MIKOLAJa KOPERNIKA 
REDAKTOR NACZELnY: Maciej Grochowski

Rada Redakcyjna: Ireneusz Bobrowski (Kraków), Andrzej Bogusławski (Warszawa), Gerd Hentschel (Niemcy, Oldenburg), Axel Holvoet (Litwa, Wilno), Krystyna Kleszczowa (Katowice), Roman Laskowski (Kraków), Jarmila Panevová (Czechy, Praha), Jens Nørgård-Sørensen (Dania, Kopenhaga), Zuzanna Topolińska (Macedonia, Skopje), Daniel Weiss (Szwajcaria, Zurich), Anna Wierzbicka (Australia, Canberra)

Kole gi u m R e D K C Y J e: Maciej Grochowski, Krystyna Kallas, Irena Sawicka, Piotr Stalmaszczyk

S E K R ETA R Z R E D A K C I: Iwona Kaproń-Charzyńska

A D R E S R E D A K C J I: Instytut Języka Polskiego UMK, 87-100 Toruń, ul. Fosa Staromiejska 3, e-mail: lincop@umk.pl,www.linguistica.umk.pl

OKŁ A D K A: Monika Pest

(C) Copyright by Wydawnictwo Naukowe Uniwersytetu Mikołaja Kopernika

Toruń 2012

ISSN 2080-1068

Wersją pierwotną (referencyjną) czasopisma jest wersja papierowa.

WYDAWNICTWO NAUKOWE UNIWERSYTETU MIKOEAJA KOPERNIKA

Redakcja: ul. Gagarina 5, 87-100 Toruń

tel. (56) 6114295 , tel./fax 6114705

e-mail: wydawnictwo@umk.pl

Dystrybucja: ul. Reja 25, 87-100 Toruń

tel./fax (56) 61142 38, e-mail: books@umk.pl

www.wydawnictwoumk.pl

Druk: Wydawnictwo Naukowe UMK 


\section{Terminative in Egyptian - a process of grammaticalization}

Keywords: grammaticalization, terminative, Egyptian, prefixation, auxiliary verb

As Heine said, grammaticalization theory is not a theory, but rather a way of describing particular processes of language change (Heine 2003: 575). In that process lexemes and lexical items, also morphosyntactic strings or whole constructions become grammatical categories. In many cases grammatical forms become more grammatical (ibid.; Traugott 2003: 624).

In reconstructing dead languages grammaticalization theory allows to use materials from different periods of time to support each other in establishing meanings of individual morphemes and constructions. In exchange, reconstructed languages with long history as written languages are invaluable sources for grammaticalization studies.

\section{Terminative in Egyptian}

Terminative was a rare form in Egyptian, but despite this remained present in the language from Old Egyptian until Coptic, sustaining its meaning and most characteristic feature .t. Because of this feature, in studies on Old and Classical Egyptian the term 'terminative' is not used, the form is known only by its paradigm $s \underline{d m} . t=f$. It is consistent with other verbal forms of 
a type: verb $(s \underline{d} m-$ 'to hear') (+ ending) + pronominal suffix or noun $(=f$ is a pronominal suffix of the third person masculine: 'he', 'his').

Origins of the $s \underline{d} m . t=f$ form are not certain. What evokes confusion is that all the verbs except for strong ones take ending . $t$ also in several other forms, most notably in infinitive. Also endings .tw or .ty were usually abbreviated only to .t.

Sethe's early theory (Verbum, t. II: $462, \S 357)$, that $s \underline{d m} . t=f$ originates from infinitive, was based on the mentioned similarity of forms and the fact that in Egyptian infinitives were frequently nominalised and could take pronominal suffix with possessive ( $s \underline{d} m=f$ meaning 'his hearing', $i r . t=f-$ 'his doing'). It was soon rejected (Gunn 1924: 174-175) and Erman, supported by Gunn, suggested that $s \underline{d} m . t=f$ contains feminine infinitival form (Gunn, 1924: 179). A different view was presented by Gardiner, who assumed that the form originated in perfective passive participle ( $G r \S 405)$.

Apart from discussion on grammatical origins of the form, its actual meaning is also a subject of debate. Although scholars agree on a mostly uncontroversial convention for translating compounds in which the form occurs, the meaning of a lone $s \underline{d} m . t=f$ remains unclear. Gardiner noted that with prepositions the form describes action which is relatively past $(G r \S 407)$, and Allen considers it to "express the action of the verb as completed" (2004, 22.16). According to Zonhoven (1996: 633-634) it has the meaning of a relative-future tense. ${ }^{1}$

\section{2. $s \underline{d} m . t=f$ in Old and Classical Egyptian}

In the texts of Old Egyptian a number of certain examples of usage of $s \underline{d} m . t=f$ was preserved. It appeared mainly in two compounds: $n s \underline{d} m . t=f$ and $\underline{d} r s \underline{d} m . t=f$.

$n$ in Old and Classical Egyptian is a frequent type of negation. With $s \underline{d} m . t=f$ it means '(he) has not yet (heard)' $(G r \S 402)$ or 'while (he) has not yet (heard)' (Zonhoven 1996: 616), e.g.:

$n$ hpr.tpt "the heaven has not yet come to existence" (PT 1466c).

${ }^{1}$ Egyptian, especially Old and Classical, did not differentiate grammar tenses, but only aspects. 
$\underline{d} r$ is a preposition with the basic meaning 'since', 'from' (Wb V, 592.1-593.1). In a compound with $s \underline{d} m . t=f$ in Old Egyptian it gets the meaning 'before' ( $A \ddot{a} G \S 735)$ :

$\underline{d} r \check{s} d . t=k k 3 n N$. $r$ pt tn "before you take the $k a$ of $\mathrm{N}$. to that heaven" (PT 815c).

In both these compounds a verb can take passive form just as well as active. The most certain examples of it are attested since Classical Egyptian (cf. Zonhoven 1998a).

There is no certain evidence for the appearance of $r s \underline{d m} . t=f$ compounds in Old Egyptian, well attested since Middle Kingdom. Although there are a number of examples which seem plausible, considering their context, all of them contain a week verb, and therefore may simply be nominalised infinitive ( $A \ddot{a} G$ §734). There are no other contexts of usage of $s \underline{d} m . t=f$ in Old Egyptian texts. ${ }^{2}$

In Classical Egyptian ${ }^{3}$ both the compounds from Old Egyptian were preserved, with $\underline{d} r \underline{d} \underline{d m} . t=f$ getting wider meaning: 'before', 'until', 'since', 'from the moment' ( $G r$ §407). Compound with $\mathrm{r}$ also became relatively frequent. $r$ was a common preposition, also used as conjunction with the meaning 'until', 'so that' (Wb II, 388.6-7):

$r r h . t=k s h r w[=i]$ "until you get to know my situation" (Fowler, 39).

Verbs appearing in $s \underline{d m} . t=f$ after prepositions could be negated with $t m$, negation characteristic especially for nominalized forms:

$r t m . t=k m n h r t=f$ "until thou art not troubled about his condition" (Ptahhotep, following Gardiner, $\mathrm{Gr} \S 408$ ).

It is also possible that $s \underline{d} m . t=f$ appeared after several other prepositions: $m$ ('when'), $m-h t$ ('after'), hft ('when'), $m i$ ('like', 'according as'). However, there are no preserved examples of such usage with strong verbs, therefore all

2 Edel mentions also usage as object after verb ( $A \ddot{a} G \S 739)$, but this interpretation has been widely rejected as not containing $s \underline{d} m . t=f$ form but an infinitive.

3 In English literature often referred also as Middle Egyptian. 
of these appearances might in fact have been only infinitives $(G r \S 407, A \ddot{a} G$ $\S 785)$.

Despite several uncertainties, it may be said that in Old and Classical Egyptian $s \underline{d} m . t=f$ was a form with a constant meaning, which could be preceded by an adequate pronoun or negation typical for such verbal forms.

\section{Terminative in Late Egyptian}

Late Egyptian began to be used in spoken language ca. $1600 \mathrm{BC}$, but until late XVIII dynasty Classical was the only written language. ${ }^{4}$ The reign of Akhenaten brought an abrupt change. Although Classical Egyptian remained the standard language for hieroglyphic inscriptions, everyday writing was adjusted to the spoken form.

$\underline{d} r s \underline{d} . t=f$ had already become very rare by the XVIII dyn. and in XIX dyn. it disappeared entirely (on the possible reasons see: Zonhoven 1996: 625, 634-635). $r s \underline{d} m . t=f$ and $n s \underline{d m} . t=f$ both remained relatively frequent in XVIII dyn., until the change occurred.

\section{Main verb > auxiliary verb}

One of the main grammatical differences between Classical and Late Egyptian was the introduction of - in the second of them - auxiliary verbs (cf. Feder 2004). Auxiliaries, rarely and unregularly present in Classical became fully grammaticalized in Late Egyptian. Forms of $s \underline{d} m=f$, standard verbal constructions in Classical, became rarely used and in few of their original meanings.

The $s \underline{d} m . t=f$ form seems to be unusually persistent. $r s \underline{d m} . t=f$ could still be found in the texts of XIX dyn., although more rarely (Winand found up to five such examples, see: 1992, §468). In the negated form $n$ was exchanged for $b w$ (as in several other types of sentences), and the form $b w s \underline{d m} . t=f$ can be found until the reign of Ramesses III.

Concurrently periphrastic forms appear. During the XIX dyn. the negated form of terminative could take several different auxiliary verbs: iri (originally 'to do' and still used also as a main verb), $r h$ ('to know'), $r d i$ ('to give'), or $\check{s} m$ ('to go'). $b w i r . t=f s \underline{d} m$, for the first time attested during the reign of Se-

${ }^{4}$ Cf. Appendix. 
thos I, became the only form used since Ramesses III's reign (Winand 1992, $\S 459-462)$. In that form terminative was used until Demotic.

hr bw ir.t=kh3b n=infr bin "But you have not yet sent to me, good or bad." (i.e. with a good or bad message) (p. Nevill, V, 3-4).

\section{Preposition > prefix}

Development of $r s \underline{d m} . t=f$ was quite different, clearly both those forms were separated and speakers of the language lost awareness of their common descent. iri, the most popular auxiliary verb of Late Egyptian, was also the only one which - since XIX dynasty - could be used with this form. Therefore, $r i r . t=f s \underline{d} m$ appeared. However, phonetic changes played a strong role there. As $r$ in Late Egyptian pronunciation was commonly lenited to $i$ and $i$. was a prefix appearing in several verbal forms, $r$, which originally was a preposition, underwent prefixation and as early as during the reign of Sethos I the form $i . i r . t=f s \underline{d} m$ appeared - maintaining its original meaning ('until (he heard)'), ${ }^{5}$ e.g.:

$m t w=t n s 3 w t 3 y=s$ ht i.ir.t $(=i)$ iy "guard its seal until I come." (LRL, $47,12-13)$.

It cannot be said for how long Egyptians were aware of the origins of a prefix $i$. in that form, but certainly not after late XX dyn., when new a preposition, $\check{3}^{\zeta}$, began to be used.

\section{Main verb > preposition}

$\zeta^{3}$ itself was originally a verb, which appeared during First Intermediate Period with the meaning 'to begin' (Hannig 2003: 1280). Since the XVIII dyn. it started to appear as a compound with prepositions, most notably with $r$, getting prepositional usage and meaning. In Late Egyptian it could already appear alone (presumably also as a result of strong lenition of $r$ ) as the preposition (with the meaning 'to', 'until'), despite still being used as a verb (cf. Wb IV, 407.8-409.2).

${ }^{5} i$. should be understood as reinterpreted as prefix rather than clitic because of a characteristic sequence of signs which were used to write it. 


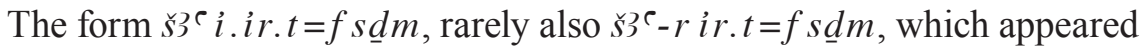
in the late XX dyn., should be considered an effect of partial grammaticalization, as no other preposition with equivalent meaning was being used with $i . i r . t=f s \underline{d} m$. More importantly, very soon, in XXI dyn., it was reinterpreted.

\section{Preposition $>$ auxiliary verb}

Presumably as an effect of the lenition mentioned before, $i . i r$ in that particular form ceased to be considered as a verb, at least in some cases, and a shortened form, $\check{s}^{c} . t=f s \underline{d} m$, appeared. In that form $\check{s}^{c}{ }^{\complement}$ took a role of an auxiliary verb, despite the fact that in many other forms $i r i$ was still used as an auxiliary and was generally recognised as such. Most probably it was an effect of a concurrent use of $\xi^{c}$ as a preposition and a verb and the consistency with which $3_{3}{ }^{C}$ was appearing in the terminative. (For development of $r$ $s \underline{d} m . t=f$ form in Late Egyptian cf. Winand 1992, §462-470; Černy and Groll 1975, 415-417; Neveu 1996: 199-200; Junge 2005: 99.)

For several centuries both forms (with the same meaning) could be used, as it can be well observed in the Story of Wenamun - preserved on a papyrus from the XXII dyn. (Caminos 1977: 3), e.g.:

imi in.tw $=f \breve{s} 3$ i. ir.t=i šm r rsy "Have it brought (here) until I go south." (LES 70, 12)

$\breve{s}^{\top} . t=w g m p 3 y=k i t 3 y$ "until they will find your thief." $(\operatorname{LES} 62,15)$.

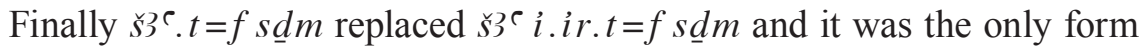
which was preserved until Demotic.

It should be also mentioned that in Late Egyptian $t$, especially at the end of a word, was usually not pronounced and often omitted in writing. $s \underline{d} m . t=f$ was an unusual case in which $t$ was preserved not only until the moment when Late Egyptian became a written language, but until it was replaced by Demotic in later stages of the language. It is certain due to $w$, which was frequently written after $t$ (hence common transliteration of this unit: . $t w$ ) and was the typical way of showing that a particular $t$ should be pronounced, especially when it was preceding suffix or other close unit (Kruchten 2000). In that context it is interesting to observe that in texts from the Third Intermediate Period or later written in Classical Egyptian . $t$ in $s \underline{d m} . t=f$ forms were usually omitted - ap-

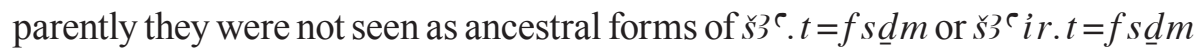


anymore (Zonhoven 1998b). Dissociation between terminative forms in Late Egyptian can be observed already in their different paths of change, but it is possibly an even stronger example of autonomy of a phrase due to the process of grammaticalization (cf. Bybee 2003: 617-618).

\section{Terminative in Demotic and Coptic}

$\breve{s}_{3}{ }^{c} . t=f s \underline{d} m$, or rather, as it was pronounced at that time, $\breve{s}^{c} \cdot t=f s t m^{6}$ was a form preserved through all the time of Demotic language. However, with time 3 was more and more frequently omitted. On the other hand, in some of the texts from Roman times ' is replaced by $n$, giving a form $\breve{3} n . t=f \mathrm{stm}$. (Lexa 1948, §741)

\section{Auxiliary verb $>$ prefix (with nouns)}

That form was later realized in classical Sahidic dialect of Coptic: ()גмт $\overline{\mathbf{9}} \mathrm{COT \overline {M }}$ (shantefsotem), still preserving characteristic meaning 'until (he hears/heard)' and - more rarely - 'so that' (Layton 2004, §349, Till 1978 $\S 312)$. In an example with a noun:

()дитетпе пдрдге (shantetpe parage) "until the Heaven passes" (Mt 5, 18; following Till, 1978 §312)

However, in some of the dialects base $\omega^{2} \lambda \mathrm{T}=($ shat $=)$ or $\left.\mathrm{c}\right) \lambda \mathrm{Te}=($ shate $=)$ was used (Lexa 1948, §741), clearly indicating that in some regions Demotic form $\check{s}(3)^{\ulcorner} . t=f$ stm was preserved.

$b w$ ir. $t=f s \underline{d} m$ came to Demotic in its form unchanged since the XIX dyn. However, $w$ became frequently omitted: $b(w) i r . t=f$ stm (Lexa 1948, §693). Gradually that form was replaced by $b(w) p(3) . t=f s t m$, using different auxiliary verb $p(3)$, which was being used in several other forms as well (Lexa $1948, \S 740)$.

Auxiliary verb and pronominal suffix $>$ agglutinative prefix (with pronouns)

${ }^{6}$ Phonetic change $\underline{d}>d>t$ actually started already in Classical Egyptian. But in some words - like $s \underline{d} m$ - it was advancing slowly, and even slower was its realization in the written language. 
The second of the mentioned Demotic forms can be seen in Coptic base

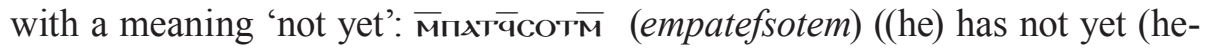
ard)) (Layton 2004, §336).

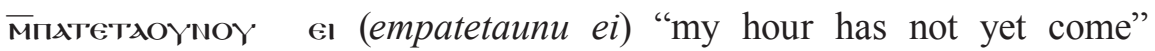
(John 2, 4; following Till 1978 §320)

In Coptic, forms of terminative - just like many other verbal forms - underwent prefixation and became agglutinative affixes.

\section{Grammaticalization of Egyptian terminative}

In the history of the development of Egyptian terminative form several main changes can be observed:

- main verb $>$ auxiliary verb

- main verb $>$ preposition

- auxiliary verb $>$ prefix

- auxiliary verb and pronominal suffix $>$ agglutinative prefix

- preposition > auxiliary verb

- preposition $>$ prefix.

In general, the process observed here is an example of a typical pattern: main verb $>$ auxiliary $>$ affix (cf. Hopper and Traugott 1993: 108-112). That process is accompanied by some other mechanisms which are well known to occur in grammaticalization, e.g. phonetic reduction in Demotic forms (cf. Bybee 2003: 615-617), decategorialization (especially by prefixation). The changes are also congruent with the overlap model (cf. Heine 2003: 579).

However, some much rarer changes may be observed here as well. Probably the most atypical was a change from preposition to auxiliary verb (cf. Campbell 2004: 294-296). For such a change to undergo a co-occurrence of three facts had to occur. First of all, the preposition used in a set phrase with a verbal form originated from the verb which was still at use. Secondly, general phonetic change strongly reduced auxiliary verb of the mentioned set phrase. Finally, the set phrase could not appear with any other preposition or without it. All these circumstances led to reinterpretation of a preposition, which began to be used as an auxiliary.

The other interesting fact is a lack of extension (context generalization) in the case of $3^{C}$ as an auxiliary verb. It appeared quite late, when it was generally settled which types of sentences take which auxiliaries (in contrast with 
XIX dyn., cf. example of $b w s \underline{d m} . t=f$ ). However, shifts were still happening (like in the case of $b(w) p(3) . t=f s t m$ ). Despite that terminative remained the only form with which $\varsigma^{\prime} \subset$ as an auxiliary could be used. It may be considered as an effect of an unusual way in which $\varsigma_{3}{ }^{\circ}$ began to be used as an auxiliary verb - nevertheless, as the word became fully grammaticalized, extension would be expected.

Terminative in Egyptian was a highly specialized form, used rarely and in clearly defined contexts. That allows us to assess frequency of different compounds in different periods of time and observe how grammaticalization was progressing step by step - not only when words were changing their grammatical category, but also how words were becoming gradually more strongly connected - from a collocation, with all the mid-steps, to the creation of two ostensibly unrelated forms.

\section{Bibliography}

AäG: EDEL E., 1955/1964, Altägyptische Grammatik, Roma.

Allen J. P., 2004, Middle Egyptian: An introduction to the language and culture of hieroglyphs, Cambridge: University Press.

BiOr: Bibliotheca Orientalis.

Bybee J., 2003, Mechanisms of change in grammaticization: the role of frequency, In:

B. D. Joseph and R. D. Janda (eds.), The handbook of historical linguistics. 602-623 , Oxford: Blackwell.

Caminos R. A., 1977, A Tale of Woe from a Hieratic Papyrus in the A. S. Pushkin Museum of Fine Arts, Oxford: Griffith Institute, Ashmolean Museum.

CAmpbell L., 2004, Historical linguistics: an introduction, Edinburgh: Edinburgh University Press.

Černy J., Groll S. I., 1975, A Late Egyptian Grammar, Rome: Pontifical Biblical Institute.

Feder F., 2004, Das Ende des "narrativen" Infinitivs im Sinuhe, LingAeg, 12, pp. 53-74.

Fowler: The Discourse of the Fowler. Edition: Parkinson R. B., 2004, "The Discourse of the Fowler": Papyrus Butler Verso (P. BM EA 10274), JEA, 90, pp. 81-111.

Gr: GARDINER A., 1957, Egyptian grammar: Being an introduction to the study of hieroglyphs, Oxford: Griffith Institute.

Grimal N., 2002, A history of ancient Egypt, Oxford: Cambridge, MA: Blackwell.

GunN B., 1924, Studies in Egyptian syntax, Paris: Librairie Orientaliste Paul Geuthner. 
Hannig R., 2003, Ägyptisches Wörterbuch I: Altes Reich und Erste Zwischenzeit, Mainz am Rhein.

Heine B., 2003, Grammaticalization, in: B. D. Joseph and R. D. Janda (eds.), The handbook of historical linguistics, 575-601, Oxford.

Hopper P. J., Traugott E. C., 1993, Grammaticalization. Cambridge.

JEA: Journal of Egyptian Archaeology.

Junge F., 2005, Late Egyptian Grammar: An introduction, Oxford: Griffith Institute.

Kruchten J.-M., 2000, Assimilation and dissimilation at work in the Late Egyptian verbal system: The verb forms built by means of the auxiliary iri from the second part of the Nineteenth Dynasty until early Demotic, JEA, 86, pp. 57-65.

Layton B., 2004, A Coptic grammar: With chrestomathy and glossary: Sahidic dialect, Wiesbaden: Harrassowitz Verlag.

LES: Late Egyptian Stories. Edition: GARdiner A., 1932, Late-Egyptian Stories, Bruxelles: Fondation égyptologique Reine Elisabeth.

LeXA F., 1948, Grammaire démotique IV: Morphologie 2. verbe II: Formes composées $d u$ verbe, Praha: F. Lexa.

LingAeg: Lingua Aegyptia: Journal of Egyptian Language Studies.

LRL: Late-Ramesside Letters. Edition: ČERNY J., 1939, Late Ramesside Letters, Bruxelles: Edition de la Fondation Egyptologique Rein Elisabeth.

Neveu F., 1996, La langue des Ramsès: Grammaire du néo-égyptien. Paris: Khéops.

p. Nevill. Edition: Barns J., 1949, The Nevill Papyrus, JEA, 35, pp. 69-71.

PT: Pyramid Texts. Edition: Sethe K., 1969, Die altägyptischen Pyramidentexte, vol. 1-3. Hildesheim.

Verbum: SETHE K., 1899, Das aegyptische Verbum im altaegyptischen neuaegyptischen und koptischen, vol. 1-3, Leipzig.

TILl W. C., 1978, Koptische Grammatik (Saïdischer Dialekt) Mit Bibliographie, Lesestücken und Wörterverzeichnissen, Leipzig: Verlag Enzyklopädie.

Trugott E. C., 2003, Constructions in grammaticalization, in: B. D. Joseph and R. D. Janda (eds.), The handbook of historical linguistics. 624-647, Oxford.

Wb: ERman A., Grapow H., 1971, Wörterbuch der ägyptischen Sprache, vol. 1-5, Berlin: Akademie-Verlag.

Winand J., 1992, Études de néo-égyptien, vol. 1: La morphologie verbale, Liège: Centre informatique de philosophie et lettres.

Z̈̈S: Zeitschrift für Ägyptische Sprache und Altertumskunde.

Zonhoven L., 1996, Studies on the $s \underline{d m} . t=f$ verb form in Classical Egyptian, I: The construction $\underline{d} r s \underline{d}$. $t=f$. BiOr, 53, 613-644.

Zonhoven L., 1998a, Studies on the $s \underline{d m} . t=f$ verb form in Classical Egyptian, IV: The passive $s \underline{d m} . t=f / m s .(y) t=f . Z \ddot{A} S, 125,78-92$. 
Zonhoven L., 1998b, Studies on the $s \underline{d} m . t=f$ verb form in Classical Egyptian, V:

The relative future tense $s \underline{d} m . t=f . \mathrm{BiOr}, 55,600-642$.

\section{Appendix - Timeline}

Stages in the development of Egyptian language (Allen, 2004: 1; Layton, 2004: 1):

- early inscriptions - before $3000 \mathrm{BC}$ until $2600 \mathrm{BC}$.

- Old Egyptian - ca. 2600 BC until ca. 2100 BC.

- Classical (Middle) Egyptian - ca. 2100 BC until 1600 BC as a spoken language, used in writing until Akhenaten's reign and - for hieroglyphic inscriptions - for the rest of the history of ancient Egypt.

- Late Egyptian - used as a spoken language since ca. 1600 BC, replaced Classi$\mathrm{cal}$ in writing during Akhenaten's reign, used until ca. $600 \mathrm{BC}$.

- Demotic - appeared ca. $650 \mathrm{BC}$, last attested text come from $5^{\text {th }}$ century AD.

- Coptic - first time attested at the end of $1^{\text {st }}$ century AD, last texts written by native speakers come from $11^{\text {th }}$ century; remains in use among learned Copts until $19^{\text {th }}$ century, used nowadays in a Coptic Orthodox Church liturgy.

Chronology of Pharaonic Egypt, extract (Grimal, 2002, Appendix):

- 4500-3150 BC - predynastic period

- 3150-2700 BC - Thinite Period

- 2700-2190 BC - Old Kingdom

- 2200-2040 BC - First Intermediate Period

- 2040-1674 BC - Middle Kingdom

- 1674-1553 BC - Second Intermediate Period

- 1552-1069 BC - New Kingdom

- 1552-1314/1295 BC - XVIII dyn.

- 1352-1338 - Amenophis IV/Akhenaten

- 1295-1188 BC - XIX dyn.

- 1294-1279 BC - Sethos I

- 1188-1069 BC - XX dyn.

- 1186-1154 BC - Ramesses III

- 1069-702 BC - Third Intermediate Period

- 1069-945 BC-XXI dyn.

- 945-715 BC - XXII dyn.

- 747-525 BC - Late Period

- 525-404 BC - First Persian Period

- 404-343 BC - dynasties XXVIII-XXX

- 343-332 BC - Second Persian Period

- 332-304 BC - Macedonian Dynasty

- 304-30 BC - Ptolemaic Period 


\section{Terminativus $\mathrm{w}$ języku egipskim - proces gramatykalizacji ( streszczen ie)}

Forma terminativu, w staroegipskim i klasycznym egipskim znana jako $s \underline{d} m . t=f$, występowała we wszystkich etapach języka egipskiego, aż do koptyjskiego.

Autorka artykułu analizuje zmiany, które zaszły w tej formie na skutek procesu gramatykalizacji. Zmiany te $\mathrm{w}$ znacznym stopniu zgodne były $\mathrm{z}$ dobrze znanym schematem: czasownik główny > czasownik posiłkowy > prefiks, schematem, który jest powszechnie obserwowalny w rozwoju języka egipskiego. Jednakże, zachodziły tam także inne, bardziej nietypowe mechanizmy. W artykule ukazano okoliczności, w jakich takie mechanizmy mogą wystąpić, w szczególności: rolę mających miejsce w języku zmian fonetycznych oraz współwystępowanie słów należących do różnych części mowy, ale pochodzących od tego samego słowa. Egipski, który był językiem pisanym przez niemal cztery tysiące lat, pozwala wskazać takie nietypowe przykłady i określić ich pochodzenie oraz późniejszy rozwój w dłuższym okresie. 